\title{
CONCEPTUALIZATION OF INTELLIGENCE AND STUPIDITY IN BULGARIAN AND ROMANIAN PHRASEOLOGY
}

\author{
CRISTINA-ANDREEA RADU-BEJENARU \\ IORGU IORDAN - ALEXANDRU ROSETTI INSTITUTE OF LINGUISTICS \\ UNIVERSITY OF BUCHAREST \\ andreea_radubejenaru@yahoo.com
}

In this paper we focus on some of the most important features of idioms, motivation and compositionality, in particular. The introductory part deals with theoretical aspects of the new linguistic discipline known as cognitive studies. From a cognitive point of view, idioms are figurative linguistic units which exist at the intersection point of language, cognition and culture. The main idea, which we support, is that of Dobrovol'skij, one of the first linguists to apply the theory of conceptual metaphors in idiom analysis. In the second part of the paper we continue - as stated in the introduction - with an analysis of some Bulgarian and Romanian idioms that express the concept of intelligence or stupidity.

Keywords: phraseology, cognitive studies, conceptual metaphors, Bulgarian and Romanian phraseological units

\section{REFERENCES}

Кирилова 2017: Кирилова, Й. Представата за ума в българската езикова картина на света. София, ДиоМира. [Kirilova 2017: Kirilova, Y. Predstavata za uma v balgarskata ezikova kartina na sveta. Sofia, DioMira.]

Dobrovol'skij 2005: Dobrovol'skii, D., Piirainen, E. Figurative Language: Crosscultural and cross-linguistic Perspectives. Oxford, ElsevierAcademic Press.

Dobrovol'skij 2010: Dobrovol'skij, D., E. Piirainen, Idioms: Motivation and etymology. - Yearbook of Phraseology, Vol. 1, p. 73-96. Berlin, Walter de Gruyter GmbH \& Co Publishing House.

Ionescu 2017: Ionescu, D. Food idioms and proverbs in English and Romanian. A cross-linguistic and cross-cultural approach. Bucharest, Oscar Print.

Lakoff\&Johnson 1980: Lakoff, G., M. Johnson. Metaphors we live by. Chicago, University of Chicago Press.

Langlotz 2006: Langlotz, A. IdiomaticCreativity: A cognitive-linguistic model of idiom-representation and idiom-variation in English. Amsterdam/Philadelphia, John Benjamins Publishing Company.

Pamies Bertrán 2011: Pamies Bertrán, A. Phraséologie et compétence métaforique: universaux cognitifs vs. héritage culturel. - В: Езиковедски изследвания в чест на проф. Сийка Спасова-Михайлова. София, АИ „Проф. Марин Дринов“, с. 58-78. [Pamies Bertrán 2011: Pamies Bertrán, A. Phraséologie et compétence métaforique: universaux cognitifs vs. héritage culturel. - In: Ezikovedski izsledvaniya v chest na prof. Siyka Spasova-Mihaylova. Sofia, AI „Prof. Marin Drinov“, s. 58-78.] 
Zafiu 2004: Zafiu, R. Păcatele limbii:Prostia comparată. - In: România Literară, № 39. http://www.romlit.ro Web. 15 Aug. 2018.

Zaharieva 1997: Zaharieva, S. Dicționar frazeologic român-bulgar. София, АИ „Проф. Марин Дринов“. [Zaharieva 1997: Zaharieva, S. Dicționar frazeologic român-bulgar. Sofia, AI „Prof. Marin Drinov“.]

$\triangle$ Cristina-Andreea Radu-Bejenaru

"Iorgu Iordan - Al. Rosetti" Institute of Linguistics University of Bucharest

Bucharest, Romania 